Rev. Bras. Saúde Prod. Anim., Salvador, v.16, n.3, p.470-485 jul./set.., 2015 http://www.rbspa.ufba.br

\title{
Asymmetries and similarities in horse production in the Southern of Brazil and Argentina: productivity, health and trade aspects
}

\author{
Assimetrias e similaridades na produção de cavalos no sul do Brasil e Argentina: \\ produtividade, aspectos sanitários e comerciais
}
OLIVEIRA, José Evandro Gervasio de ${ }^{1 *}$; ALMEIDA, Fernando Queiroz de ${ }^{2}$; GUEDES, Cezar Augusto Miranda ${ }^{2}$; TRIGO, Pablo Ignacio ${ }^{2}$; SILVA, Vinicius Pimentel ${ }^{2}$; OLIVEIRA, Chiara Albano de Araujo ${ }^{2}$; LEITE, Gilberto Gonçalves ${ }^{3}$; RODRIGUES, Raphael $^{1}$

${ }^{1}$ Exercito Brasileiro, Santa Maria, Rio Grande do Sul, Brasil.

${ }^{2}$ Uiversidade Federal Rural do Rio de Janeiro, Instituto de Veterinaria, Seropedica, Rio de Janeiro, Brasil.

${ }^{3}$ Universidade de Brasilia, Faculdade de Agronomia e Medicina Veterinária, Brasília, Distrito Federal, Brasil.

*Endereço para correspondência: evandro.gervasio@gmail.com

\section{SUMMARY}

This study was carried out in order to verify the asymmetries and similarities in horse breeding in the Brazilian South region and Argentina, analyzing the productive, health and trade aspects. Data collection were performed with questionnaires in fieldwork (primary sources) and bibliographic searches and surveys (secondary sources). The sample consisted of horses breeders in Brazil, Rio Grande do Sul State, and in Argentina. The questionnaire was based on the Brazilian Study of Horse Agribusiness Complex, divided into: Production Aspects, Health Issues and trade aspects. Descriptive data analysis and relative frequencies were compared using the chi-square $\left(\chi^{2}\right)$ test at $5 \%$ probability. It was observed that there was a similarity in several aspects related to the breeding and trade horse agribusiness, whereas in the health aspects there was asymmetry in certain aspects. In the Southern Brazil, $29.0 \%$ of the owners live in the breeding farm and $67.7 \%$ have another remunerated activity. There was a similarity in the endoparasites system control and an asymmetry in the ectoparasites control. There was a higher percentage of diseases control in Argentina, which may be related to technification and qualification of workforce. However, regarding the equine sanitary control, there was a similarity between the farms of Southern Brazil and Argentina. Despite of all asymmetries and similarities, there is a relevance of horse agribusiness on generating jobs and income source, as well as the cultural and economic contribution in both countries. Furthermore, there is a necessity of public policies from government authority to promote the horse industry.

Keywords: agribusiness, animal production, equine breeding

\section{RESUMO}

O objetivo com este estudo foi observar as similaridades e asimetrias existentes na criação de cavalos no sul do Brasil e Argentina, a partir de análise dos aspectos produtivos, comerciais e da saúde dos equinos. A metodologia utilizada compreendeu levantamento de dados, através de aplicação de questionário a campo (fontes primárias) e pesquisas bibliográficas (fontes secundárias). A amostragem abrangeu criadores de equinos do Rio Grande do Sul e Argentina. O questionário foi elaborado baseado no Estudo do Complexo do Agronegócio Cavalo no Brasil, dividido em: Aspectos de Proodução, Sanitários e Comerciais. Foi realizada análise descritiva dos dados e as frequências relativas foram comparadas pelo teste Qui-quadrado $(\mathrm{P}<0,05)$. Observou-se similaridades nos aspectos relacionados à criação e comercialização, mas assimetria relacionada à saúde dos equinos. No sul do Brasil 29,0\% dos proprietários vivem da 
Rev. Bras. Saúde Prod. Anim., Salvador, v.16, n.3, p.470-485 jul./set.., 2015 http://www.rbspa.ufba.br ISSN 15199940

criação de cavalos, enquanto $67,7 \%$ exercem outras atividades remuneradas. Observou-se similaridade no controle de endoparasitas e assimetria em relação à ectoparasitas. A alta percentagem de controle de doenças observada na Argentina pode estar relacionada à tecnificação e a mão de obra treinada. Contudo, observou-se similaridade entre as fazendas do sul do Brasil e Argentina em relação ao controle sanitário dos rebanhos de equinos. A respeito das diversas assimetrias e semelhanças observadas, destaca-se a importância do agronegócio cavalo na produção de emprego e renda, bem como a contribuição econômica e cultural para ambos os países. Além disso, há necessidade de políticas públicas para a promoção da indústria do cavalo.

Palavras-chave: agronegócio, criação de equinos, produção animal

\section{INTRODUCTION}

The equine culture takes a prominent position in the Brazilian and Argentine agricultural scenario, therefore, should be further explored and studied, particularly regarding the generation of employment and the contribution to the families income in these two countries.

The equine breeding agribusiness, in both countries, involves over thirty segments, that can be sorted in inputs, breeding and ultímate use. It generates around 3.2 million direct and indirect jobs in Brazil (LIMA et al., 2006) and 180 thousand direct and indirect jobs in Argentina (OLIVA, 2011).

The herd of horses in Argentina is approximately 2.5 million heads (SENASA, 2009) and Brazil's 5.6 million heads (IBGE, 2009), the largest herd in Latin America and fourth world (FAO, 2011). Totalizing 8 million heads when mules and donkeys are considered.

The equine breeding agribusiness moves around $\mathrm{R} \$ 7.3$ billion a year, in both Brazil and Argentina. The horses are most used in the agriculture, but also used for sports, leisure and military activities, such as equotherapy.

The world horsemeat trade is promising, despite beeing unknown by the general population, it contributes to the trade balance in many countries. In Brazil the potential of the horsemeat production is still incipient, however, it presents itself as a new opportunity in agribusiness. The world's largest exporter of horsemeat is Argentina, while Brazil is the fifth (OLIVA, 2011). The objective of this study was to verify the asymmetries and similarities of productive, health and trade aspects of horse breeding in Rio Grande do Sul, Brazil, and in Argentina.

\section{MATERIAL AND METHODS}

This study used data collection with questionnaires in fieldwork and direct observation of production systems, riding clubs, Jockey Clubs, Universities, Research Institutes as primary sources. And bibliographic searches and surveys as secondary sources. Which allowed comparison with other similar cases, collected from official agencies and scientific papers, printed or available online, allowing theoretical embasement.

The sample analyzed consisted of horse breeds from Rio Grande do Sul state, Brazil, and Argentina. The sample was intentionally non-probabilistic, since the goal was to identify the asymmetries and similarities of breeds proportionally to the farms visited and researched, in order to describe the breeding farms in Southern Brazil and Argentina.

The inclusion criterion was the presence of a minimal organizational structure on property, including: stallion/semen, mares (minimum of five), stalls, paddocks, technical and veterinary/animal science 
Rev. Bras. Saúde Prod. Anim., Salvador, v.16, n.3, p.470-485 jul./set.., 2015 http://www.rbspa.ufba.br

professional/agronomist and an annual production of three horses.

All data analyzed was based on quantitative and qualitative data collection, observation, document analysis, formal interview and a questionnaire with closed questions given on the visits to the pre-selected properties. It is important to emphasize that a survey regarding the breeds with most incidence in the region was made in order to evenly distribute the proportion of visits. The questionnaire was also sent to the breeds associations and some farms in order to increase the accuracy of the information.

The questionnaire was prepared based on the Brazilian Study of Horse Agribusiness Complex (LIMA et al., 2006) and other points to meet the research objectives. It was divided into: Production Aspects (46 questions related to animals and property identification, physical farms structure, production planning, animal husbandry, training for skilled worker, financial and labor issues), Health issues (12 questions related to veterinarian monitoring, preventive measures and treatments) and trade aspects (5 questions related to the objectives of production, business and marketing). The proposed construction of the questionnaire was a research tool, focused on enabling the analysis of selected studies, meeting the goals for analyzing the asymmetries and similarities of the horse production.

In Southern Brazil approximately fifty questionnaires were hand out by mail and e-mail, and almost forty visits to farms were made. In Argentina thirty questionnaires were hand out by e-mail or on visits to the farms, and more forty visits were made to breeding and training centers. In both countries, interviews were conducted with the veterinarians responsable for the horses in order to obtain data on reproduction and sanitary aspects. Also, several horses auctions were analyzed in several categories, such as broodmares, colts and training horses, with the purpose of obtaining data on commercial aspects during the internal and external sales.

Data selection, analysis and interpretation were performed at the end of the interview period. Thus, only those data that filled the requirement were analyzed. In Southern Brazil, it was selected four of 50 surveys hand out (by mail or internet) and 27 of the 40 visits, totalizing 31 selected in 90 . In Argentina, five of the 30 hand out (internet or personal delivery) were aproved, and 35 of the 40 from the visits. Total of 40 samples selected from Argentina (Humid pampa region).

The data collected were tabulated and a descriptive analysis was performed by Statistical Package for Social Science (SPSS Inc. 2006) version 15.0.

Nonparametric analysis of frequencies was also performed, a contingency table $2 \times 2$ was compared using chi-square $(\chi 2)$ at $5 \%$ probability using the InStat statistical package.

\section{RESULTS AND DISCUSSION}

In Southern Brazil $70.9 \%$ of horses breeders breed Criollo horses, while in Argentina, only $15 \%$ of them breed animals of this breed, a fact that features an asymmetry. It was observed that the Criollo breed is the most important and numerous horse in the breeding system of Rio Grande do Sul. This finding corroborates with breed association ABCCCBH (2012) that reports the existence of 9.589 breeders, which corresponds to $85 \%$ of total breeding sites (Table 1). Although the Criollo 
Rev. Bras. Saúde Prod. Anim., Salvador, v.16, n.3, p.470-485 jul./set.., 2015 http://www.rbspa.ufba.br ISSN 15199940

horse has had its origins in the Argentine Pampas, therefore native from this region, its relevance is low when compared to other breeds analyzed in Argentina, such as the Polo and Thoroughbred breeds. In Argentina, there is a homogeneous distribution in breeding sites of different breeds. However, according to Oliva (2011), Polo and Thoroughbred holds up $42 \%$ of the animals in activities.

Table 1 . Horse breeds produced in the properties analyzed

\begin{tabular}{lrrrr}
\hline \multirow{2}{*}{ Breeds } & \multicolumn{2}{c}{ Southern Brazil } & \multicolumn{2}{c}{ Argentina } \\
\cline { 2 - 5 } & $\mathrm{f}$ & \multicolumn{1}{c}{$\%$} & $\mathrm{~F}$ & \multicolumn{1}{c}{} \\
\hline Thoroughbred & 4 & 12.9 & 6 & 15.0 \\
Arabians & 0 & 0.0 & 6 & 15.0 \\
Brazilian Sport Horse & 2 & 6.5 & 0 & 0.0 \\
Criollo & 22 & 70.9 & 6 & 15.0 \\
Quarter Horse & 3 & 9.7 & 5 & 12.5 \\
Sela Argentina & 0 & 0.0 & 3 & 7.5 \\
Polo & 0 & 0.0 & 7 & 17.5 \\
Other races & 0 & 0.0 & 7 & 17.5 \\
\hline Total & 31 & 100.0 & 40 & 100.0 \\
\hline Where f is the frequency & & & &
\end{tabular}

Where $\mathrm{f}$ is the frequency.

There is a lack of Brazilian horse breeding sites in Argentina and the same situation is observed in Brazil, where Sela Argentina and Argentine Polo are not bred in the South. That is because these breeds are exclusive from its country and there is not a strong enough political effort to import.

Regarding the reprodutive planning of horses, $37 \%$ of properties in Southern Brazil do the planning, against $7 \%$ that do not perform $(\mathrm{P}<0.01)$, as well as in Argentina were $39 \%$ of properties do the planning and $17 \%$ answered they do not. When compared, there was a similarity between the localities analyzed in both countries, there was no difference $(\mathrm{P}>0.05)$ from breeding sites in Southern Brazil and Argentina, since both regions have a reproduction plan in their system. Likewise, the use of reproduction biotechnologies was similar in both regions, with $48.3 \%$ of use in animal breeders in Southern Brazil and 57.5\% in Argentina (Table 2).

It should be noted that high number of properties using only natural breeding can be explained by the restriction imposed by breed association related to reproductive biotechnologies used on Thoroughbred and Criollo, that are predominant in Southern Brazil and Argentina.

Several authors evaluated the reproductive performance as a way to determine management techniques and ensure the reproductive efficiency of the horse breed system (FREITAS, 2005, PAPA et al., 2005). The processes of reproductive biotechnology pointed out by these authors, allowed significant development and, with transfer of embryos, fast evolution of breeding and genetic improvement, making the cost / benefit ratio more attractive for the breeder (LIRA et al., 2009). 
Rev. Bras. Saúde Prod. Anim., Salvador, v.16, n.3, p.470-485 jul./set.., 2015 http://www.rbspa.ufba.br ISSN 15199940 http://dx.doi.org/10.1590/S1519-99402015000300001

Table 2. Reproductive biotechniques used in Southern Brazil and Argentina

\begin{tabular}{lrrrr}
\hline \multirow{2}{*}{ Reproductive biotechniques } & \multicolumn{2}{c}{ Southern Brazil } & \multicolumn{2}{c}{ Argentina } \\
\cline { 2 - 5 } & $\mathrm{F}$ & $\mathrm{\%}$ & $\mathrm{f}$ & $\%$ \\
\hline Natural breeding & 16 & 51.6 & 17 & 42.5 \\
FAI & 4 & 12.9 & 1 & 2.5 \\
PS & 4 & 12.9 & 0 & 0.0 \\
FAI, FzAI, PS & 2 & 6.5 & 8 & 20.0 \\
FAI, FzAI, PS, TE & 1 & 3.2 & 2 & 5.0 \\
FAI, PS & 1 & 3.2 & 0 & 0.0 \\
FAI, FzAI & 1 & 3.2 & 0 & 0.0 \\
FAI, FzAI, TE & 1 & 3.2 & 0 & 0.0 \\
FAI, FzAI, PS, TE, EP & 0 & 0.0 & 12 & 30.0 \\
Uninformed & 1 & 3.2 & 0 & 0.0 \\
\hline Total & 31 & 100.0 & 40 & 100.0 \\
\hline
\end{tabular}

Where $\mathrm{f}$ is the frequency; FAI $=$ Fresh Artificial Insemination, PS = Purchase of semen; FzAI = Frozen Artificial Insemination; TE $=$ Transfer of embryos, EP $=$ Embryos Purchase.

Properties management models were compared with the size of the property, whether the owner lived in the location, whether he pursued another remunerated activity and way of management. It was found out that the distribution of property size in Southern Brazil is homogeneous among small, medium and large farms
(Table 3). This feature tends to have similarities with those observed in Argentina distribution. The properties considered medium size, from 251 to 1000 ha, tend to have homogeneous frequencies in both countries, with $45.1 \%$ and $47.5 \%$ in Southern Brazil and Argentina, respectively.

Table 3. Horse breeding system properties size in Southern Brazil and Argentina

\begin{tabular}{lrrrr}
\hline \multirow{2}{*}{ Size (ha) } & \multicolumn{2}{c}{ Southern Brazil } & \multicolumn{2}{c}{ Argentina } \\
\cline { 2 - 5 } & $\mathrm{f}$ & \multicolumn{1}{c}{ 年 } & 11 & $\%$ \\
\hline$\leq 250$ & 9 & 29.0 & 17 & 27.5 \\
\hline $251-500$ & 9 & 29.0 & 2 & 42.5 \\
$501-1000$ & 5 & 16.1 & 10 & 5.0 \\
\hline$>1000$ & 8 & 25.9 & 40 & 100.0 \\
\hline Total & 31 & 100.0 & & \\
\hline
\end{tabular}

Where $\mathrm{f}$ is the frequency.

In Southern Brazil 29.0\% of owners live in breeding sites and $67.7 \%$ have other remunerated activity. Asymmetrically in Argentina, all the owners have remunerated work, and only $2.5 \%$ live in the property (Figure 1). This can be explained by the fact that in Argentina the largest concentration of horse breeding systems are located near urban centers, while in the South of Brazil they are more distant. It can be therefore concluded that the farms in Argentina are an income complement to the horse breeder, and in Brazil, where farmers live in the property, this activity must be their primary income source.

It was observed that $83.9 \%$ and $90.0 \%$ of the properties in Southern Brazil and Argentina, respectively, are managed by owners and/or other family members, featuring as family business (Figure 2). 
Rev. Bras. Saúde Prod. Anim., Salvador, v.16, n.3, p.470-485 jul./set.., 2015 http://www.rbspa.ufba.br ISSN 15199940

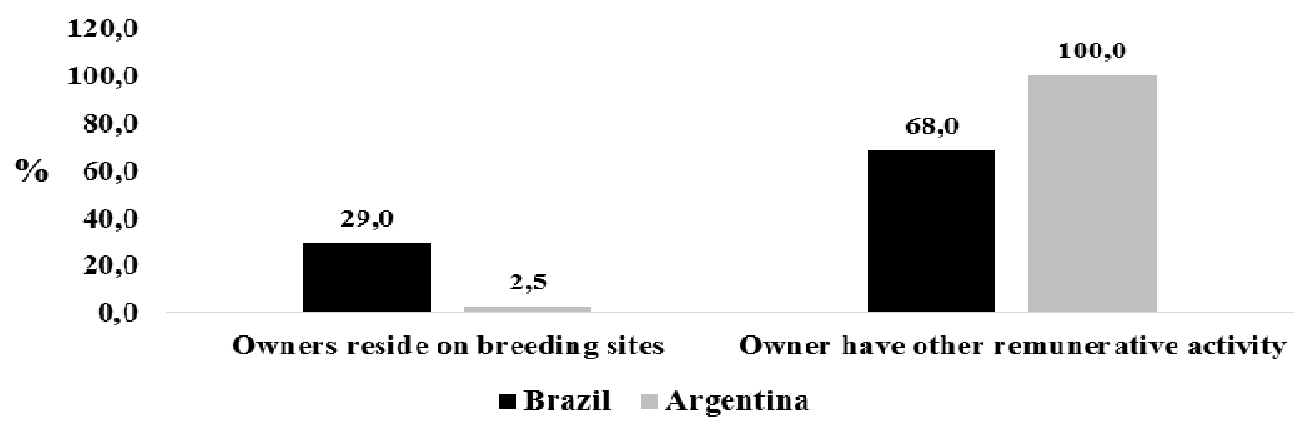

Figure 1. Management characteristics of horse breeding properties in Southern Brazil and Argentina

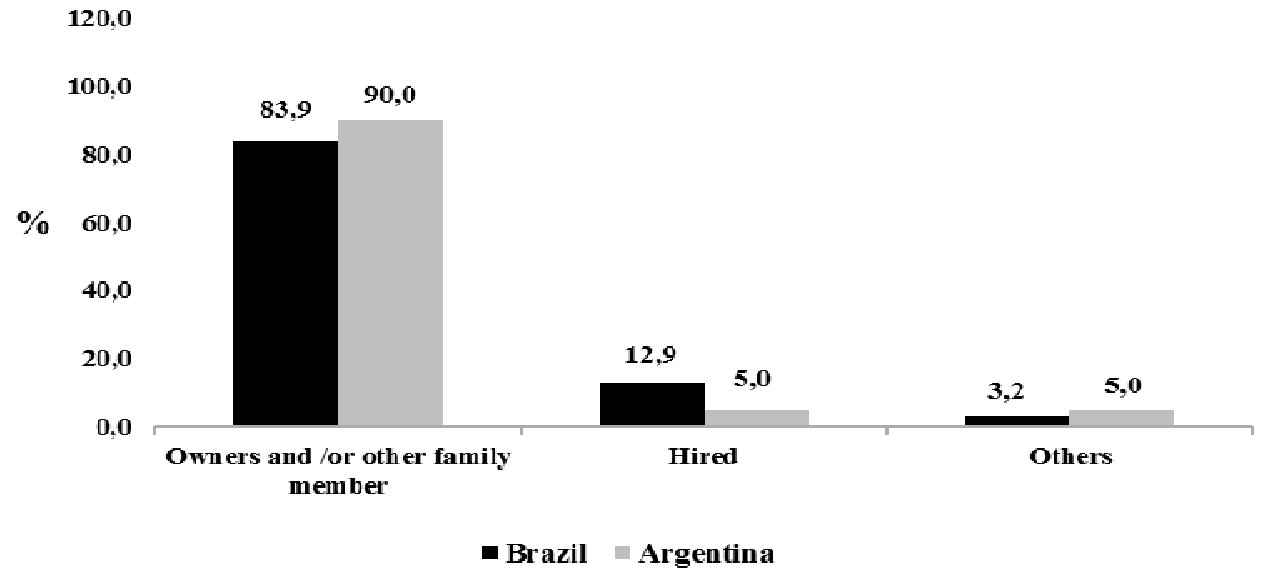

Figure 2. Management method of horse breeding properties in Southern Brazil and Argentina

This fact indicates that breeding horses is a family business activity performed on weekends and days off, inserted in Agribusiness Equine Complex, which according to Lima et al. (2006) represents a prominent position in developed and developing countries. The family property management can be explained by the fact that most of breeding sites are sources of supplementary income and there is no room for the costs of hiring specialized staff for the job.

No difference was observed between properties in Southern Brazil regarding the use of temporary labor $(\mathrm{P}>0.05)$, $25 \%$ of properties analyzed use it and $18 \%$ do not use. However, in Argentina, it was observed that $46 \%$ of properties do not employ temporary labor $(\mathrm{P}<0.05)$, while only $10 \%$ do. This fact indicates that in Argentina the workforce is more professional or qualified than in the South of Brazil. Therefore, the temporary labor, possibly less specialized and cheaper, takes place in periods of higher demand of services in Southern Brazil.

As for the benefits offered to the hired staff such as: transportation, board and lodging support, it was observed that in Southern Brazil, 38\% of the properties analyzed provided some benefit, while 6\% did not. In Argentina it was observed similar distribution, with $49 \%$ offering some kind of benefit and 7\% $(\mathrm{P}<0.01)$ not 
Rev. Bras. Saúde Prod. Anim., Salvador, v.16, n.3, p.470-485 jul./set.., 2015 http://www.rbspa.ufba.br ISSN 15199940

offering benefits for their employee. The level of education of the staff of the horse breeding in Southern Brazil and Argentina is similar when it comes to college level. This can be explained by the need of diverse professionals: veterinarians, agronomists and animal scientists. However, the percentage of manpower with high school degree and basic education is significantly lower in Argentina. This result might show higher levels of specialized labor use in Argentina (Figure 3). Moreover, the higher use of less specialized labor in Brazil is possibly due to the low amount paid to farm workers.

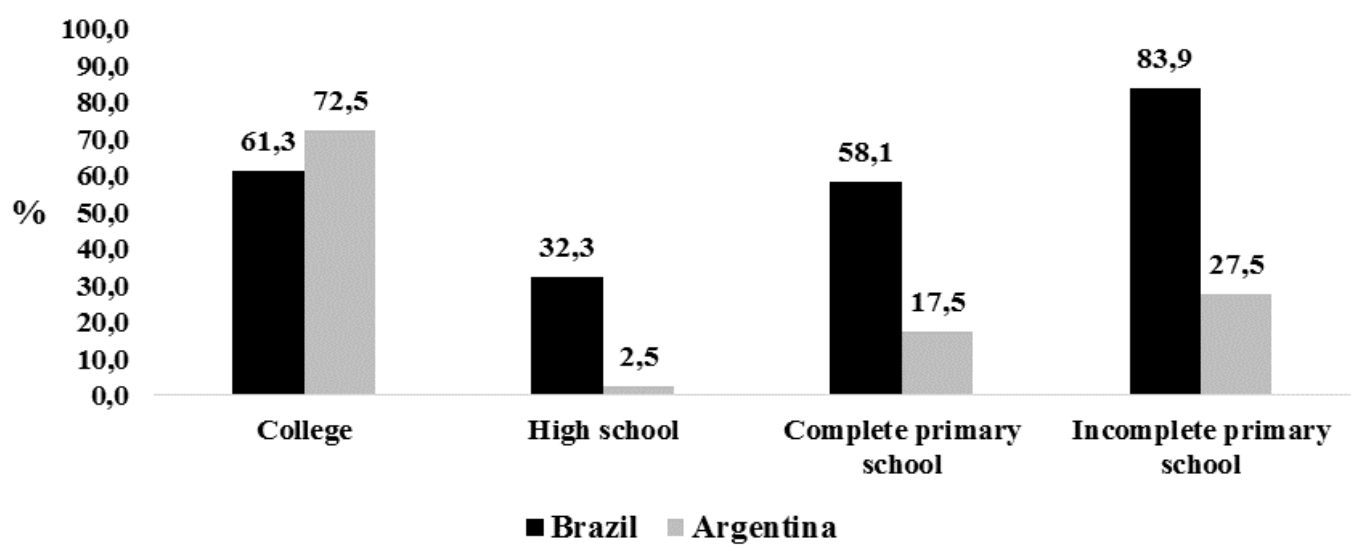

Figure 3. Level of education of employed manpower in horse breeding properties in Southern Brazil and Argentina

The horses training systems adopted in the stables has an asymmetry between the two countries. The rational training, or natural horsemanship is more used in Argentina (75\%). The conventional training use has a similarity between Southern Brazil and Argentina, and the percentage observed was $32.3 \%$ and $22.5 \%$, respectively (Table 4 ). It is suggested that employment of working labor is higher in Argentina as the technification of farms, this fact could influence the natural horsemanship use. The health aspects adopted by the owners analyzed on this study allowed the observation of a similarity in endoparasites control (Figure 4). The endoparasites control is a similarity factor between the regions studied, the use of dewormers is around $96.8 \%$ and $95 \%$, in
Southern Brazil and Argentina, respectively. However regarding to ectoparasites control, $51.6 \%$ of properties in Southern Brazil use it, against 7.5\% in Argentina. This diference can be explained by unfavorable weather conditions to ticks and other arthropods growth and proliferation in Argentina, especially in colder regions like the Southern Andes and Patagonia.

In Southern Brazil the control of leptospirosis, adenitis equine and rhinopneumonitis diseases are performed by vaccination in $32.3 \%$; $41.9 \%$ and $32.3 \%$, respectively, of the properties. In Argentina $65.0 \%$ of the properties perform some prophylaxy against adenitis and $62.5 \%$ against equine rhinopneumonitis, however, only $7.5 \%$ do it for leptospirosis. 
Rev. Bras. Saúde Prod. Anim., Salvador, v.16, n.3, p.470-485 jul./set.., 2015 http://www.rbspa.ufba.br ISSN 15199940

Table 4. Horsemanship technique used in equine production systems in Southern Brazil and Argentina

\begin{tabular}{lrrrr}
\hline \multirow{2}{*}{ Training } & \multicolumn{2}{c}{ Southern Brazil } & \multicolumn{2}{c}{ Argentina } \\
\cline { 2 - 5 } & $\mathrm{f}$ & $\%$ & $\mathrm{f}$ & $\%$ \\
\hline Natural Horsemanship (rational) & 15 & 48.3 & 30 & 75.0 \\
Conventional Horsemanship & 10 & 32.3 & 9 & 22.5 \\
Do not perform & 2 & 6.5 & 0 & 0.0 \\
Uninformed & 4 & 12.9 & 1 & 2.5 \\
\hline Total & 31 & 100.0 & 40 & 100.0 \\
\hline
\end{tabular}

Where $\mathrm{f}$ is the frequency.

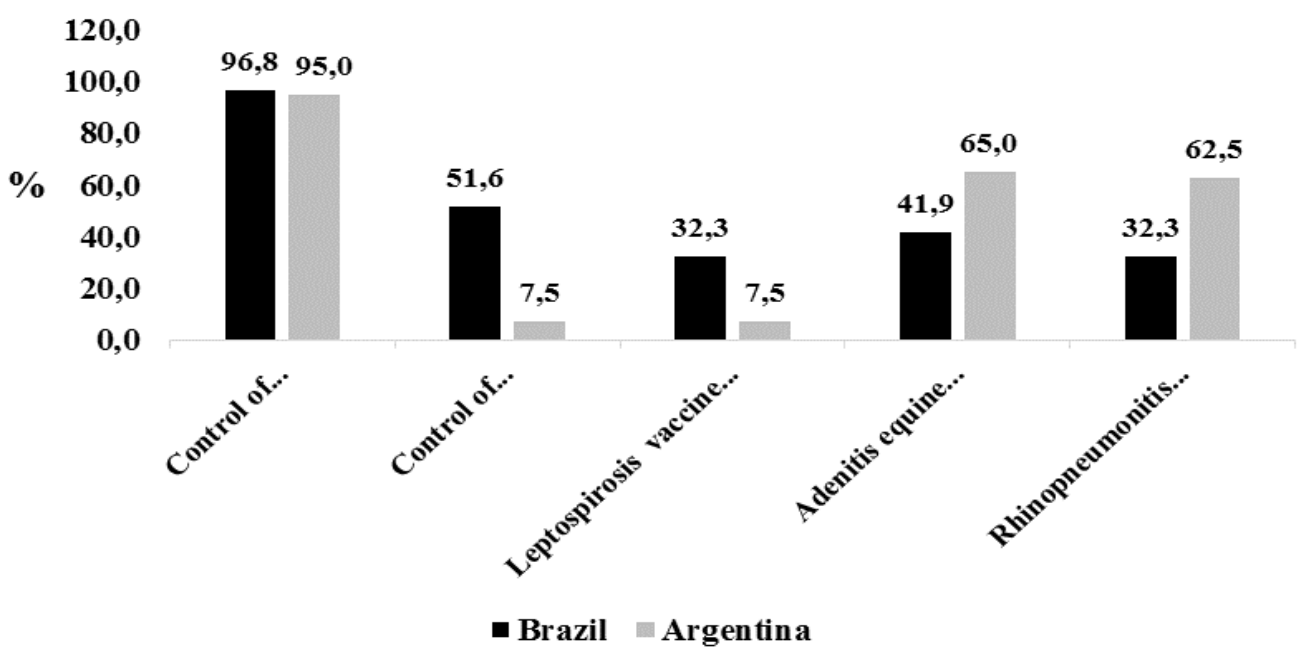

Figure 4. Health care on horse production systems in Southern Brazil and Argentina

The winter was considered the period of the year with the highest incidence of diseases in Southern Brazil (51.6\%), however, in Argentina the winter and the summer were indicated as critical periods $(82.5 \%)$ (Figure 5). It is noteworthy that the lack of data record was observed in most of the properties, and the information observed are referent to the preceding year of the present survey. Notably, it appears that there is a higher incidence of respiratory diseases in the winter and of parasitic infestations in the summer.

For the main diseases reported in Southern Brazil there is a highlight for colic and locomotor diseases, while in Argentina, there is a higher parasitic incidence (babesiosis) in the northern region, however most of the country area is considered to be a disease free zone. It is noteworthy that a high percentage of the properties managers do not hold nosological information affecting their herd, $38.7 \%$ and $67.5 \%$ in Southern Brazil and Argentina, respectively (Table 5).

The use of veterinary services is higher $(\mathrm{P}<0.01)$ in Southern Brazil $(30 \%)$ compared with Argentina (18\%), thus an asymmetry $(\mathrm{P}<0.01)$ between countries can be observed. 
Rev. Bras. Saúde Prod. Anim., Salvador, v.16, n.3, p.470-485 jul./set.., 2015 http://www.rbspa.ufba.br ISSN 15199940

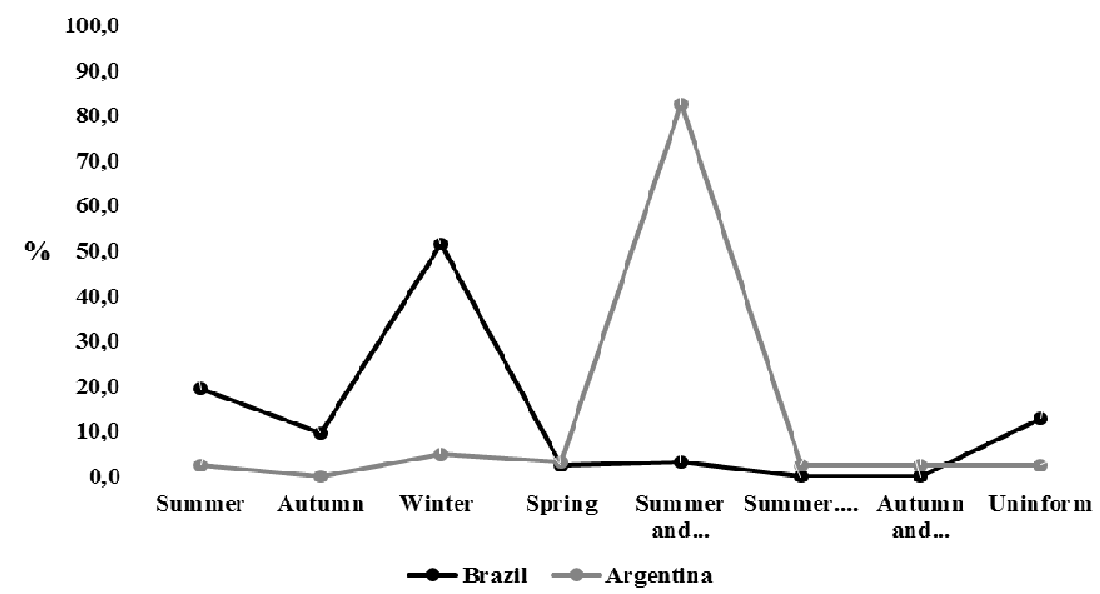

Figure 5. Seasonality of diseases incidence in horses in Southern Brazil and Argentina

Table 5. Horse diseases occurrence in horse production systems in Southern Brazil and Argentina in 2010

\begin{tabular}{lrrrr}
\hline \multirow{2}{*}{ Diseases } & \multicolumn{2}{c}{ Southern Brazil } & \multicolumn{2}{c}{ Argentina } \\
\cline { 2 - 5 } & $\mathrm{f}$ & $\%$ & $\mathrm{f}$ & $\%$ \\
\hline CR & 5 & 16.1 & 0 & 0.0 \\
AS & 4 & 12.9 & 1 & 2.5 \\
BB & 2 & 6.5 & 7 & 17.5 \\
PN & 0 & 0.0 & 1 & 2.5 \\
CR, DI & 0 & 0.0 & 2 & 5.0 \\
CR, DI, PN & 2 & 6.5 & 1 & 2.5 \\
CR, AS & 1 & 3.2 & 0 & 0.0 \\
DI, AS & 1 & 3.2 & 0 & 0.0 \\
CR, BB & 1 & 3.2 & 0 & 0.0 \\
CR, DI, AS, PN & 1 & 3.2 & 0 & 0.0 \\
CR, DI, AS, PN, BB & 1 & 3.2 & 0 & 0.0 \\
AS, PN & 1 & 3.2 & 0 & 0.0 \\
AS, PN, O & 0 & 0.0 & 1 & 2.5 \\
Uninformed & 12 & 38.7 & 27 & 67.5 \\
\hline Total & 31 & 100.0 & 40 & 100.0 \\
\hline Wheryyyyyy
\end{tabular}

Where $\mathrm{f}$ is the frequency; $\mathrm{CR}=$ Cramps; $\mathrm{AS}=$ Locomotor; $\mathrm{BB}=$ Babesiosis; $\mathrm{PN}=$ Pneumonia; $\mathrm{DI}=$ Diarrhea; $\mathrm{O}=$ Other.

It was observed that most properties analyzed does not use any diagnostic procedure for detection of diseases in breeding sites, although there is tendency for using it in properties in Southern Brazil, due to the presence of the resident veterinarian, with percentage of $32.3 \%$ (Table 6). This fact is related to the soaring use of veterinary services at the same region. It was very often observed that properties in Argentina did not indicate if they use or not any diagnostic procedure to detect diseases, therefore, a more careful analysis on the topic is affected. Stricter sanitary control over visitors is performed in Southern Brazil. Although the comparison was not significant $(p>0.05)$, this indicates that almost half of the properties required attention. 
Rev. Bras. Saúde Prod. Anim., Salvador, v.16, n.3, p.470-485 jul./set.., 2015 http://www.rbspa.ufba.br ISSN 15199940

However, in Argentina, a different value was observed with $41 \%$ of properties not performing any control (Table 7).

A high technification level was observed in the analyzed properties in Southern Brazil and Argentina (Table
8). Both regions use some kind of technified activity with use of some type of machinery. This can better be explained by the fact that all properties selected presented at least some organization level.

Table 6. Use of diagnostic for diseases detection in equine production systems in Southern Brazil and Argentina

\begin{tabular}{lcccc}
\hline \multirow{2}{*}{ Diagnostic use } & \multicolumn{2}{c}{ Southern Brazil } & \multicolumn{2}{c}{ Argentina } \\
\cline { 2 - 5 } & $\mathrm{f}$ & $\%$ & $\mathrm{f}$ & $\%$ \\
\hline Veterinary resident & 10 & 32.3 & 3 & 7.5 \\
Laboratory / University, State Service & 2 & 6.5 & 1 & 2.5 \\
Uninformed & 19 & 61.2 & 36 & 90.0 \\
\hline Total & 31 & 100.0 & 40 & 100.0 \\
\hline
\end{tabular}

Where $\mathrm{f}$ is the frequency.

Table 7. Health control from visitors in equine production systems in Southern Brazil and Argentina

\begin{tabular}{lccc}
\hline Health control & Southern Brazil (\%) & Argentina (\%) & Total (\%) \\
\hline Presence & $18.0^{\mathrm{Aa}^{*}}$ & $15.0^{\mathrm{Aa}}$ & 48.0 \\
Absence & $25.0^{\mathrm{Aa}}$ & $41.0^{\mathrm{Ba}}$ & 52.0 \\
\hline Total & 44.0 & 56.0 & 100.0 \\
\hline
\end{tabular}

*Different letters, uppercase in columns and lowercase letters in rows, differ by Chi-square (5\%).

Table 8. Use of machinery in horse breeding systems in Southern Brazil and Argentina

\begin{tabular}{lccc}
\hline Machinery & Southern Brazil (\%) & Argentina $(\%)$ & Total $(\%)$ \\
\hline Presence & $38.0^{\mathrm{Aa}}$ & $55.0^{\mathrm{Aa}}$ & 93.0 \\
Absence & $6.0^{\mathrm{Ba}}$ & $1.0^{\mathrm{Ba}}$ & 7.0 \\
\hline Total & 44.0 & 56.0 & 100.0 \\
\hline${ }^{*}$ Different letters, uppercase in columns and lowercase letters in rows, differ by Chi-square (5\%).
\end{tabular}

Regarding to the ingredients destinated to feed horses, no significant diferences were observed in Southern Brazil. Therefore, the values of food producer properties and non-producer are similar, with values of 18 and $25 \%$, respectively. In Argentina, however, the amount of properties that produces some type of food was significantly higher, from $37 \%$ to $20 \%$, respectively. However, when compared, there was no difference between regions of both countries $(p>0.05)$.

According to Hijano \& Bacigalup (1995) can be stated that native grassland from Argentina is composed of about $90 \%$ native lucerne (crioula), a legume with more than $20 \%$ of crude protein with high dry matter yield. It can be inferred that the native grasslands from Argentina are richer 
Rev. Bras. Saúde Prod. Anim., Salvador, v.16, n.3, p.470-485 jul./set.., 2015 http://www.rbspa.ufba.br ISSN 15199940

and more productive compared to Southern Brazil.

The Southern Brazil and Argentina show the same pattern for produced food, however, are different in relation to the number of producer properties (Table 9). The hay and the oat are the most produced in both regions, due to the increasing use of these ingredients on concentrated rations destinated to feed horses. The fact that lower rate of hay production properties were observed in Southern Brazil, with values of $19,4 \%$, might explain the higher incidence of digestive system diseases, $16.1 \%$, due to low fiber content in the diet. According to Braga et al. (2008) diets with less than $25 \%$ of neutral detergent fiber promotes changes in fibrinogen plasma level and might increase the susceptibility for clinical laminitis and colic.

Table 9. Types of food produced in properties with production systems for horses in Southern Brazil and Argentina

\begin{tabular}{|c|c|c|c|c|c|c|c|c|}
\hline \multirow{3}{*}{ Item } & \multicolumn{4}{|c|}{ Southern Brazil } & \multicolumn{4}{|c|}{ Argentina } \\
\hline & \multicolumn{2}{|c|}{ Yes } & \multicolumn{2}{|c|}{ No } & \multicolumn{2}{|c|}{ Yes } & \multicolumn{2}{|c|}{ No } \\
\hline & $\mathrm{f}$ & $\%$ & $\mathrm{f}$ & $\%$ & $\mathrm{f}$ & $\%$ & $f$ & $\%$ \\
\hline Hay & 6 & 19.4 & 25 & 80.6 & 26 & 65.0 & 14 & 35.0 \\
\hline Corn & 2 & 6.5 & 29 & 93.5 & 0 & 0.0 & 40 & 100.0 \\
\hline Oatmeal & 8 & 25.8 & 23 & 74.2 & 7 & 17.5 & 33 & 82.5 \\
\hline Others & 2 & 6.5 & 29 & 93.5 & 1 & 2.5 & 39 & 97.5 \\
\hline Concentrate diet & 0 & 0.0 & 31 & 100.0 & 0 & 0.0 & 40 & 100.0 \\
\hline
\end{tabular}

Where $\mathrm{f}$ is the frequency.

The presence of horses concentrated feeding management in both areas surveyed did not differ $(\mathrm{P}>0.05)$ (Table 10). The concentrate ration is a food rich in crude protein and digestible energy supplementation needed in categories with higher nutritional requirements.
Such use is most frequently observed in the breeding of English Thoroughbred, Sela Argentine, Brazilian and Argentine Polo Equestrian. It can de noticed that the lower frequency of the concentrated supply in Argentina (15\%) is due to the better quality of pastures in that area.

Table 10. Concentrated supply in horse production systems in Southern Brazil and Argentina

\begin{tabular}{lccc}
\hline Item & Southern Brazil (\%) & Argentina (\%) & Total (\%) \\
\hline Presence & $21.0^{\mathrm{Aa}^{*}}$ & $15.0^{\mathrm{Ba}}$ & 37.0 \\
Absence & $23.0^{\mathrm{Aa}}$ & $41.0^{\mathrm{Aa}}$ & 63.0 \\
\hline Total & 44.0 & 56.0 & 100.0 \\
\hline
\end{tabular}

* Different letters, uppercase in columns and lowercase letters in rows, differ by Chi-square (5\%).

Regarding the supply of hay between the breeding sites surveyed, we found no differences between Southern Brazil and Argentina in the supply of hay
$(\mathrm{P}>0.05)$. With $38 \%$ and $41 \%$, respectively, providing hay to equines and $6 \%$ and $15 \%$ do not use the hay for feeding the horses. However, there were 
Rev. Bras. Saúde Prod. Anim., Salvador, v.16, n.3, p.470-485 jul./set.., 2015 http://www.rbspa.ufba.br

no differences between regions $(\mathrm{P}>0.05)$, thereby one more similarity between the properties of Southern Brazil and Argentina. In these areas there is a greater advantage of native pastures, since $42 \%$ of properties in Southern Brazil and Argentina uses $55 \%$ them and only $2 \%$ and $1 \%$, respectively, do not use. This fact can be explained by the quality of pastures in the areas surveyed, and its use is a way to optimize the cost of power in horse breeding.
Both Southern Brazil and Argentina native pastures meet the nutritional needs of horses (Table 11), with the proportion of $37 \%$ and $56 \%$, respectively. However in $10 \%$ of the farms in Southern Brazil, the native field does not meet the nutritional requirements of animals, this can be due to a poorer quality soil or even the animal category that occupies this area, requiring food supplementation.

Table 11. Native pasture meets the nutritional needs of animals in the horses breeding systems in Southern Brazil and Argentina

\begin{tabular}{lccc}
\hline Item & Southern Brazil (\%) & Argentina (\%) & Total (\%) \\
\hline Presence & $37.0^{\mathrm{Aa}}$ & $56.0^{\mathrm{Aa}}$ & 93.0 \\
Absence & $7.0^{\mathrm{Bb}}$ & $0.0^{\mathrm{Bb}}$ & 7.0 \\
\hline Total & 44.0 & 56.0 & 100.0 \\
\hline${ }^{*}$ Different letters, uppercase in columns and lowercase letters in rows, differ by Chi-square $(5 \%$ \\
probability).
\end{tabular}

The nutritional monitoring is conducted both in Southern Brazil and Argentina with a high proportion $(\mathrm{p}<0.001)$, with values of $34 \%$ and $42 \%$, respectively, versus $10 \%$ and $14 \%$ of the properties that do not perform it, respectively. It was found that the regions are similar in this aspect, with no meaningful difference between them $(\mathrm{P}>0.05)$, so there is a symmetry between the properties of Southern Brazil and Argentina. This can be explained by the general understanding of the importance of food in breeding equine, corroborated by Cunha (1991) that cites that $60-80 \%$ of the costs in breeding horses is related to food, and that the quality and quantity of the same reflectes in animals productivity.

Regarding to the animals housing system, most breeding sites in Argentina use the field system (Table 12). This behavior is asymmetric for all animal categories, except for stallions and can be explained, again, by the difference in quality of pastures. The similarity in the percentage of properties that stable stallions is justified by the behavioral characteristics of this category, which difficults its management in field, besides their high livestock and financial value. The system for field breeding becomes more frequent, since the cost of facilities, feeding and labor are minimized, and so, in Argentina the matrices are bred exclusively in field, due to the pastures quality. In Brasil, $58,1 \%$ of the matrices are supplemented. The Brazilian Equine Production proposed by Carvalho \& Haddad (1987), recommends that the lairage should only be used by stallions or horses intended for auctions and exhibitions, ie, a small percentage of the herd, in order to reduce costs with constructions for the other categories of 
Rev. Bras. Saúde Prod. Anim., Salvador, v.16, n.3, p.470-485 jul./set.., 2015 http://www.rbspa.ufba.br ISSN 15199940

horses. It can also be observed an asymmetry in the breeding of foals in the lairage system, with around $90 \%$ of properties in Argentina that create their animals in field until the first year. This percentage tends to decrease in the second year because of the need to supplement this category, due to its fast growth (Table 13).

Table 12. Stallions lairage system and matrices in the horses breeding systems in Southern Brazil and Argentina

\begin{tabular}{lcccccccc}
\hline & \multicolumn{4}{c}{ Southern Brazil } & \multicolumn{3}{c}{ Argentina } \\
\cline { 2 - 9 } Foods & \multicolumn{2}{c}{ Stallion } & \multicolumn{2}{c}{ Matrices } & \multicolumn{2}{c}{ Stallion } & Matrices \\
\cline { 2 - 9 } & $\mathrm{f}$ & $\%$ & $\mathrm{f}$ & $\%$ & $\mathrm{f}$ & $\%$ & $\mathrm{f}$ & $\%$ \\
\hline $\mathrm{AC}$ & 3 & 9.7 & 11 & 35.5 & 12 & 30.0 & 40 & 100.0 \\
$\mathrm{E}$ & 13 & 41.9 & 0 & 0.0 & 0 & 0.0 & 0 & 0.0 \\
$\mathrm{SE}$ & 2 & 6.5 & 11 & 35.5 & 0 & 0.0 & 0 & 0.0 \\
E, SE & 12 & 38.7 & 7 & 22.6 & 28 & 70.0 & 0 & 0.0 \\
Uninformed & 1 & 3.2 & 2 & 6.5 & 0 & 0.0 & 0 & 0.0 \\
\hline Total & 31 & 100.0 & 31 & 100.0 & 40 & 100.0 & 40 & 100.0 \\
\hline
\end{tabular}

Where $\mathrm{f}$ is the frequency; $\mathrm{AC}=$ In field; $\mathrm{E}=$ Lairaged; $\mathrm{SE}=$ Semi lairaged.

Table 13. Foals lairage system in horses breeding systems in Southern Brazil and Argentina

\begin{tabular}{|c|c|c|c|c|c|c|c|c|c|c|c|c|}
\hline \multirow{3}{*}{ Food } & \multicolumn{6}{|c|}{ Southern Brazil } & \multicolumn{6}{|c|}{ Argentina } \\
\hline & \multicolumn{2}{|c|}{$\leq 1$ ano } & \multicolumn{2}{|c|}{$1-2$ anos } & \multicolumn{2}{|c|}{$>2$ anos } & \multicolumn{2}{|c|}{$\leq 1$ ano } & \multicolumn{2}{|c|}{$1-2$ anos } & \multicolumn{2}{|c|}{$>2$ anos } \\
\hline & $\mathrm{f}$ & $\%$ & $\mathrm{f}$ & $\%$ & $\mathrm{f}$ & $\%$ & $\mathrm{f}$ & $\%$ & $\mathrm{f}$ & $\%$ & $\mathrm{f}$ & $\%$ \\
\hline IF & 14 & 45.2 & 16 & 51.6 & 11 & 35.5 & 36 & 90.0 & 27 & 67.5 & 36 & 90.0 \\
\hline $\mathrm{L}$ & 7 & 22.6 & 6 & 19.4 & 7 & 22.6 & 0 & 0.0 & 0 & 0.0 & 0 & 0.0 \\
\hline SL & 2 & 6.5 & 1 & 3.2 & 1 & 3.2 & 0 & 0.0 & 0 & 0.0 & 0 & 0.0 \\
\hline $\mathrm{L}, \mathrm{SL}$ & 6 & 19.4 & 6 & 19.4 & 8 & 25.8 & 4 & 10.0 & 9 & 22.5 & 4 & 10.0 \\
\hline IF, E, SL & 0 & 0.0 & 1 & 3.2 & 1 & 3.2 & 0 & 0.0 & 4 & 10.0 & 0 & 0.0 \\
\hline Uninformed & 2 & 6.5 & 1 & $3 ., 2$ & 3 & 9.7 & 0 & 0.0 & 0 & 0.0 & 0 & 0.0 \\
\hline Total & 31 & 100.0 & 31 & 100.0 & 31 & 100.0 & 40 & 100.0 & 40 & 100.0 & 40 & 100.0 \\
\hline
\end{tabular}

Where $\mathrm{f}$ is the frequency; $\mathrm{IF}=\mathrm{In}$ field; $\mathrm{L}=$ Lairaged; $\mathrm{SL}=$ Semi lairaged.

The use of animals insurance, both in Southern Brazil and Argentina, is not often practiced (Table 14), with values of $42 \%$ and $51 \%$, respectively, $(\mathrm{p}<0.001)$. This can be explained by the difficulty in pricing the younger horses by insurers. The animals with the functional and / or sporting performance, however, have reference values for insurance, with the percentages found in approximately $7 \%$. According to the insurance market, the prices charged for annual insurance, are around $3 \%$ and $7 \%$ of the horse market value.

As for the source of financing equine breeding activity (Table 15), it was observed that the regions are similar in this regard, using $87.1 \%$ and $97.5 \%$ of their own funds on properties of Southern of Brazil and Argentina, respectively. What can be explained by the absence of public policies for the promotion and funding equine breeding in both countries, and the misconception that equine culture is 
Rev. Bras. Saúde Prod. Anim., Salvador, v.16, n.3, p.470-485 jul./set.., 2015 http://www.rbspa.ufba.br ISSN 15199940 http://dx.doi.org/10.1590/S1519-99402015000300001

linked historically to a class with greater purchasing power and therefore requires no funding incentive from the government. This view disregards that the brazilian equine culture generates more than 3.2 million of direct and indirect jobs (LIMA et al., 2006).

Table 14. Use of animals insurance in properties of horses breeding in Southern Brazil and Argentina

\begin{tabular}{lccc}
\hline Item & Southern Brazil (\%) & Argentina (\%) & Total (\%) \\
\hline Presence & $1,0^{\mathrm{Ba}^{*}}$ & $6.0^{\mathrm{Ba}}$ & 7.0 \\
Absence & $42,0^{\mathrm{Aa}}$ & $51.0^{\mathrm{Aa}}$ & 93.0 \\
\hline Total & 44,0 & 56.0 & 100.0
\end{tabular}

"Different letters, uppercase in columns and lowercase letters in rows, differ by Chi-square (5\% probability).

Table 15. Source of financing equine breeding activity culture in Southern Brazil and Argentina

\begin{tabular}{lrrrr}
\hline \multirow{2}{*}{ Resources } & \multicolumn{2}{c}{ Southern Brazil } & \multicolumn{2}{c}{ Argentina } \\
\cline { 2 - 5 } & \multicolumn{1}{c}{$\mathrm{f}$} & \multicolumn{1}{c}{$\%$} & \multicolumn{1}{c}{ f } & \multicolumn{1}{c}{$\%$} \\
\hline Own & 27 & 87.1 & 39 & 97.5 \\
Public bank & 1 & 3.2 & 0 & 0.0 \\
Other & 1 & 3.2 & 1 & 2.5 \\
Uninformed & 2 & 6.5 & 0 & 0.0 \\
\hline Total & 31 & 100.0 & 40 & 100.0 \\
\hline Where $\mathrm{f}$ is the frequency.
\end{tabular}

As for animals import and / or export made by the properties in Southern

Brazil and Argentina (Table 16), it was observed that in Southern Brazil most $(\mathrm{P}<0.001)$ does not perform such activity, representing 34\%. However, in Argentina there was no difference $(\mathrm{P}>0.05)$ denoting the proportionality of properties that perform or not international trade. It was also observed that the regions are similar in this aspect, with no difference between them $(\mathrm{P}=0.087)$.

It is noteworthy that in Brazil Thoroughbred races, Brazilian Equestrian and Criollo breeders have performed animals import and export. In Argentina, the Thoroughbred, the Sela Argentina and especially the
Argentine Polo have the largest percentage of this trade in animals. The growth of horses export in Brazil needs to be stimulated by sectoral development of horse agribusiness policies, since it is a sector that generates employment and income for the country.

Table 16. International trade performed by the properties of horses breeding in Southern Brazil and Argentina

\begin{tabular}{lccc}
\hline Item & $\begin{array}{c}\text { Southern } \\
\text { Brazil }(\%)\end{array}$ & $\begin{array}{c}\text { Argentina } \\
(\%)\end{array}$ & $\begin{array}{c}\text { Total } \\
(\%)\end{array}$ \\
\hline Present & $10.0^{\mathrm{Ba}^{*}}$ & $25.0^{\mathrm{Aa}}$ & 35.0 \\
Absent & $34.0^{\mathrm{Aa}}$ & $31.0^{\mathrm{Aa}}$ & 65.0 \\
\hline Total & 44.0 & 56.0 & 100.0 \\
\hline
\end{tabular}

*Different letters, uppercase in columns and lowercase letters in rows, differ by Chi-square (5\% probability).

The hosting/housing, transportation, training, riding courses and other equine-related services are accomplished by properties in Southern Brazil and Argentina (Table 17). In Argentina, equine culture is evident in the agricultural scenario because it involves more than thirty segments, becoming a significant employment and income source (OLIVA, 2011). 
Rev. Bras. Saúde Prod. Anim., Salvador, v.16, n.3, p.470-485 jul./set.., 2015 http://www.rbspa.ufba.br ISSN 15199940

The horses' commercialization, the frequency of use of auction and sale to other breeders is similar in both regions surveyed, with $35.5 \%$ in Southern Brazil and 55.0\% at Argentina (Table 18).

The other forms of marketing are negligible. It is noteworthy that a high percentage of properties in Southern Brazil (16.1\%) did not report the trade procedure of their animals. The transfer of ownership of livestock between breeders and buyers is favored by the existence of offices specialized in auctions, which are responsible for the bureaucratic procedure, facilitating the whole transaction. This type of trading works as a sort of financing for breeding farms and/or to individuals to purchase of new animals, since there are almost no public or private funding. Considering that the installment plans are up to 36 times, the breeders can obtain higher value animals.

Table 17. Services for horses offered by properties in Southern Brazil and Argentina

\begin{tabular}{lccc}
\hline Item & Southern Brazil (\%) & Argentina (\%) & Total (\%) \\
\hline Presence & $27.0^{\mathrm{Aa}}$ & $25.0^{\mathrm{Aa}}$ & 52.0 \\
Absence & $17.0^{\mathrm{Aa}}$ & $31.0^{\mathrm{Aa}}$ & 48.0 \\
\hline Total & 44.0 & 56.0 & 100.0 \\
\hline "Different letters, uppercase & in columns and lowercase letters in rows, differ by & Chi-square $(5 \%$ \\
probability). & & &
\end{tabular}

Table 18. Forms of equine commercialization by properties in Southern Brazil and Argentina

\begin{tabular}{lcrrr}
\hline \multirow{2}{*}{ Commercialization } & \multicolumn{2}{c}{ Southern Brazil } & \multicolumn{2}{c}{ Argentina } \\
\cline { 2 - 5 } & \multicolumn{1}{c}{$\mathrm{f}$} & \multicolumn{1}{c}{$\%$} & $\mathrm{f}$ & $\%$ \\
\hline Auction & 3 & 9.7 & 5 & 12.5 \\
Other breeders & 9 & 29.0 & 10 & 25.0 \\
Other & 1 & 3.2 & 0 & 0.0 \\
Auction and Other breeders & 11 & 35.5 & 22 & 55.0 \\
Auction, Fridges, Other & 1 & 3.2 & 0 & 0.0 \\
Auction, Other breeders, Hippic and similar & 0 & 0.0 & 3 & 7.5 \\
Other breeders, Hippic and similar & 1 & 3.2 & 0 & 0.0 \\
\hline Uninformed & 5 & 16.1 & 0 & 0.0 \\
\hline Total & 31 & 100.0 & 40 & 100.0 \\
\hline
\end{tabular}

Where $\mathrm{f}$ is the frequency.

The Southern Brazil and Argentina have similarities and asymmetries that characterize the own production system of the region. Despite the geographical proximity, there were influence of culture, economy and weather conditions in the asymmetries observed in the survey.
Clearly, there is a relevance of horse agribusiness on generating jobs and income source, as well as the cultural and economic contribution in both countries.

To contribute to the complex agribusiness and create new prospects for the development of the equine chain, 
Rev. Bras. Saúde Prod. Anim., Salvador, v.16, n.3, p.470-485 jul./set.., 2015 http://www.rbspa.ufba.br ISSN 15199940

it became evident that, in the productive aspect, there is pressing need to implement public policies for the promotion of industry in both countries. There is a need for more studies related to the different aspects of horse agribusiness, because of its importance and complexity.

\section{REFERENCES}

\section{ASSOCIAÇÃO BRASILEIRA DOS} CRIADORES DE CAVALO BRASILEIRO DE HIPISMO ABCCBH. Histórico das raças. 2012. Disponível em: $<$ http://www.brasileiro de hipismo.com.br/historico/Default.aspx $>$. Acesso em: 20 mar. 2012.

BRAGA, A.C.; ARAUJO, K.V.; LEITE, G.G.; MASCARENHAS, A.G. Níveis de fibra em detergente neutro em dietas para equinos. Revista Brasileira de

Zootecnia, v.37, n.11, p.1965-72, 2008.

CARVALHO, R.T.L.; HADDAD, C.M. A criação e a nutrição de cavalos. Rio de Janeiro: Editora Globo, 1987, 180p.

CUNHA, T.J. Horse feeding and nutrition. 2.ed. London: Academy Press, 1991. 445p.

FOOD AND AGRICULTURE ORGANIZATION - FAO. The State of World Fisheries and Aquaculture: Opportunities and challenges. Rome, 2011. 243p.

FREITAS, C.C. Aspectos do comportamento reprodutivo na monta natural de equinos da raça crioula. 2005. 59p. Dissertação (Mestrado) Universidade Federal do Rio Grande do Sul, Porto Alegre.
HIJANO, E.; BACIGALUP, D. El cultivo de la alfalfa em la República Argentina. In: HIJANO, E.; NAVARRO, A. (Eds). La alfalfa em la Argentina. Subprograma Alfalfa Mendonza: INTA, 1995. p.12-18.

INSTITUTO BRASILEIRO DE GEOGRAFIA E ESTATÍSTICA IBGE. Estatisticas de formação escolar e moradia. 2009. Disponível em: $<$ http://seriesestatisticas.ibge.gov.br/>. Acesso em 10 dez. 2011.

LIMA, R.A.S.; SHIROTA, R.; BARROS, G.S.C. Estudo do Complexo do Agronegócio Cavalo no Brasil. Piracicaba: CEPEAESALQ/USP, 2006, 250p.

LIRA, R.A.; PEIXOTO, G.C.X.; SILVA, A.R. Transferência de embriões em equinos: Revisão. Acta Veterinaria Brasilica, v.3, n.4, p.132-140, 2009.

OLIVA, M.L. La indústria hípica. 2011. Disponível em: $<$ http://caballosyopinion.com $>$. Acesso em 30 jun. 2012.

PAPA, F.O.; MELO, C.M.; DELL'AQUA, J.A.; MACEDO, L.P.; CARVALHO, A.G.; ALVARENGA, M.A.; MEDEIROS, A.S.L. Inovações metodológicas na biotecnologia de refrigeração e congelação de sêmen equino. Acta Scientiae Veterinariae, v.33, p.19-27, 2005. Suppl. 1.

\section{SENASA. South American Camelids} in Argentina. 2009. Disponível em: $<$ http://www.senasa.gov.ar>. Acesso em 12 jan. 2012.

SPSS Inc. Statistical Analysis Using SPSS. Version 15. Chicago, 2006.

Data de recebimento: 17/10/2014

Data de aprovação: 22/07/2015 